\title{
ORGANIZACYJNE I PROCEDURALNE UWARUNKOWANIA ZARZĄDZANIA PROJEKTAMI W JEDNOSTCE SAMORZĄDU TERYTORIALNEGO
}

\begin{abstract}
Celem artykułu jest identyfikacja i opis wybranych elementów systemowego rozwiązania polegającego na wprowadzeniu metody zarządzania projektami w jednostkach samorządu terytorialnego. Omówiono istotę samej metody, zwracając uwagę na możliwości jej wykorzystania w tego typu instytucjach. Odniesiono się także do wymiaru organizacyjnego orientacji projektowej. Analizie poddano zarówno wąski zakres reorganizacji, polegający na usprawnieniu przebiegu projektów, jak i wariant zmiany radykalnej, odnoszący się do wielu obszarów działalności jednostki. Następnie omówiono sposób organizacji pracy ukierunkowany na obsługę projektów oraz konieczne zmiany w procedurach postępowania dotyczących tego typu przedsięwzięć.

Schemat rozwiązania opisany $\mathrm{w}$ artykule osadzony jest w literaturze przedmiotu, a w szczególności bazuje na publikacjach przygotowanych w ramach najważniejszych metodyk zarządzania projektami - IPMA, PMI i PRINCE2. Przedstawione w nich założenia dotyczące wykorzystania omawianej metody należy przełożyć na specyfikę organizacji samorządu terytorialnego, tworząc założenia implementacyjne. Wspomniane w tytule wymiary - organizacyjny i proceduralny - to podstawowe elementy orientacji projektowej, które wytyczają jej zakres. Są to jednocześnie obszary trudne do zmiany w instytucjach publicznych, głównie ze względu na ograniczenia natury prawnej, a niekiedy także mentalnej. Jednocześnie warunki funkcjonowania współczesnych JST wymuszają poszukiwanie innowacji o charakterze organizacyjnym, które zwiększą efektywność pracy i racjonalność wydawania środków publicznych. Przedstawiony w artykule schemat zmiany wpisuje się w wymagania rynku kapitału mobilnego, zmiany prawne wynikające $\mathrm{z}$ wdrożenia kontroli zarządczej oraz trendy dotyczące implementacji budżetowania zadaniowego.
\end{abstract}

Słowa kluczowe: zarządzanie projektami, orientacja projektowa, samorząd terytorialny, JST

\section{WPROWADZENIE}

Zarządzanie projektami (projekt management) jest metodą, która może być z powodzeniem stosowana nie tylko w przedsiębiorstwach, ale także w jednostkach samorządu terytorialnego (JST). Jej wdrożenie do instytucji sektora finansów publicznych (SFP) nie jest łatwe i wymaga wielu istotnych zmian w sposobie ich funkcjonowania. Mogą one dotyczyć obszarów związanych $\mathrm{z}$ organizacją pracy czy przebiegiem różnego rodzaju procesów. Niezmiernie istotny jest jednak także aspekt kulturowy, który może być decydujący, jeśli chodzi o skuteczność wdrożenia zmian. $Z$ tego właśnie powodu wdrożenie

\footnotetext{
${ }^{1}$ Dr Jacek Strojny, Katedra Ekonomii, Wydział Zarządzania, Politechnika Rzeszowska, Rzeszów, Al. Powstańców Warszawy 8, 35-959 Rzeszów, tel. 17865 1529, mail: jstrojny@prz.edu.pl
} 
podejścia projektowego należy traktować jako innowację organizacyjną ${ }^{2}$, a sam proces wdrożenia ma niekiedy charakter rengineeringu.

Ostatnio temat reorganizacji instytucji sektora finansów publicznych staje się coraz bardziej popularnym obszarem eksploracji badawczej. Do multidyscyplinarnych analiz tego obszaru skłania trwający od 2008 r. kryzys ekonomiczny, który w kolejnych etapach obnaża nieefektywność coraz to nowych płaszczyzn polityki państwa. Na te zjawiska nakłada się obserwowany już od lat dziewięćdziesiątych trend związany ze zmianą roli instytucji odpowiedzialnych za współkreowanie procesów rozwojowych zarówno na poziomie centralnym, jak i regionalnym czy lokalnym. Stają się one w coraz większym stopniu podmiotami kształtującymi ofertę dla kapitału mobilnego, dążąc do uruchomienia procesów koncentracji na danym obszarze. Oba wymienione zjawiska mają inną charakterystykę, ale sprowadzają się $\mathrm{w}$ istocie do bardzo silnego impulsu wymagającego zmian wewnątrz instytucji sektora finansów publicznych. Powinny one działać najsprawniej i najefektywniej, generując endogeniczne czynniki sprzyjające koncentracji kapitału na danym obszarze.

W tym właśnie kontekście osadzono rozważania w niniejszym artykule, poszukując mechanizmów poszerzających zdolności JST do zwiększania poziomu konkurencyjności. Skupiono się na administracji samorządowej, ponieważ wydaje się, że tutaj znajduje się bardzo duży potencjał przedsiębiorczości. Reforma z 1999 r. stworzyła instytucjonalne ramy oddziaływania na procesy lokalne i regionalne. Ustawa z 27 sierpnia 2009 r. o finansach publicznych oraz trwające prace nad budżetowaniem zadaniowym skłaniają z kolei do poszukiwania nowej formuły działania. Niestety samorząd w coraz większym stopniu jest przytłaczany olbrzymią ilością przepisów, które wymuszają koncentrację na ich literalnym zapewnieniu. Tymczasem istotą skutecznego oddziaływania na otoczenie i budowania przewagi konkurencyjnej jest skupienie się na identyfikacji problemów i ich rozwiązywaniu. W praktyce oznacza to, że istnieje zagrożenie, że podejmowane działania restrukturyzacyjne w JST mogą mieć charakter pozorny, ukierunkowany głównie na spełnienie minimalnych warunków ustawowych (np. w zakresie kontroli zarządczej).

Podejście przedstawione $\mathrm{w}$ niniejszym artykule jest natomiast próbą poszukiwania rozwiązań, które znajdują odzwierciedlenie nie tylko w regulacjach, ale również przede wszystkim faktycznie przekładają się na sposób funkcjonowania.

\section{ISTOTA METODY ZARZĄDZANIE PROJEKTAMI ORAZ WYBRANE ASPEKTY JEJ WDROŻENIA W JEDNOSTKACH SAMORZADU TERYTORIALNEGO}

Geneza metody zarządzanie projektami jest podobna jak wielu innych narzędzi wykorzystywanych w zarządzaniu. Wiąże się bowiem ze sferą wojskową, w tym między innymi z badaniami prowadzonymi przez Stany Zjednoczone w trakcie II wojny światowej nad bronią atomową ${ }^{3}$. Bardzo złożony, obarczony presją czasu projekt Manhattan wymagał wprowadzenia nowych rozwiązań organizacyjnych, pozwalających na skuteczną pracę

\footnotetext{
2 „Innowacja to wdrożenie nowego lub znacząco udoskonalonego produktu (wyrobu lub usługi) lub procesu, nowej metody marketingowej lub nowej metody organizacyjnej w praktyce gospodarczej, organizacji miejsca pracy lub stosunkach z otoczeniem” (Oslo Manual, OECD/European Communites, s. 48).

${ }^{3}$ D. Skorupka, D. Kuchta, M. Górski, Zarządzanie ryzykiem w projekcie, Wyższa Szkoła Oficerska Wojsk Lądowych we Wrocławiu, Wrocław 2012, s. 9.
} 
multidyscyplinarnego zespołu. Skuteczność przyjętych w tym projekcie rozwiązań leży u podstaw sukcesu omawianej metody oraz jej szybkiego przełożenia na inne przedsięwzięcia w ramach programów wojskowych czy kosmicznych, a także na grunt działań biznesowych. Współcześnie, w ramach omawianej metody, rozwija się jednocześnie przynajmniej kilka podejść, w tym IPMA ${ }^{4}, \mathrm{PMI}^{5}$, PRINCE2 ${ }^{6}$, czy tak zwane podejścia zwinne, odwołujące się do manifestu AGILE7 ${ }^{7}$.

Metoda zarządzania projektami zawdzięcza swą popularność kilku podstawowym cechom. Jest oczywiście metodą uniwersalną, co oznacza, że może być wykorzystywana praktycznie we wszystkich podmiotach gospodarki narodowej - od przedsiębiorstw przez organizacje pozarządowe po instytucje SFP. Nie ma też znaczenia specyfika branży, ponieważ zbiór dostępnych narzędzi i podejść gwarantuje dobranie szczegółowego rozwiązania nie tylko do cech danej branży, ale nawet konkretnego podmiotu. Kolejna cecha wiąże się z bogactwem technik, które można zastosować do usprawnienia przebiegu zadań. Odnoszą się one zarówno do obszaru planowania i controllingu zadań, zasobów czy kosztów, jak i do skutecznego motywowania pracowników. Metoda zarządzania projektami jest więc także rozwiązaniem kompleksowym, które pozwala na wykorzystanie innych metod (na przykład Zarządzanie przez Cele czy Balanced Scorecard) w celu sprawniejszej realizacji projektów. Ponadto bardzo ważne jest to, że do obsługi omawianej metody przygotowano wiele narzędzi informatycznych. Tylko w Polsce aktualnie jest dostępnych kilkadziesiąt programów o różnym poziomie zaawansowania. Dzięki temu zarówno mikroprzedsiębiorstwa, jaki duże podmioty mogą znaleźć rozwiązanie optymalnie dostosowane do ich potrzeb oraz możliwości finansowych. Zastosowanie wielu technik, zwłaszcza związanych $\mathrm{z}$ planowaniem i controllingiem projektu, jest w praktyce możliwe za pomocą programów informatycznych. Łatwość dostępu do nich to bardzo ważna cecha wspomagająca możliwości aplikacyjne metody.

Identyfikując główne płaszczyzny, w których ramach należy analizować oddziaływanie omawianej metody na organizację, gdzie jest wdrażana, należy zwrócić uwagę na następujące $\mathrm{z}$ nich:

- zarządzanie przez cele (definiowanie i rozliczanie celów, priorytetyzacja);

- organizacja pracy (struktura organizacyjna i podział obowiązków);

- przebieg zadań (podział na procesy i projekty, procedury realizacji zadań, koordynacja portfeli zadań);

- kultura zarządzania (poziom delegowania, motywowanie pracowników, organizacja zespołów projektowych);

- kompetencje merytoryczne (znajomość technik, umiejętność obsługi dedykowanego oprogramowania).

\footnotetext{
${ }^{4}$ IPMA to organizacja zrzeszająca ludzi i organizacje zaangażowane w realizację projektów i promowanie kultury projektowej. Standardy zarządzania projektami promuje poprzez wytyczne zawarte w International Competence Baseline (ICB IPMA), na których oparto system certyfikacji. Strona internetowa organizacji: www.ipma.pl.

${ }^{5}$ PMI to organizacja o roli podobnej jak IPMA. Standardy zarządzania projektami zawarto w PMBook Guide, który jest również podstawą certyfikacji. Strona internetowa organizacji: www.pmi.org.pl.

${ }^{6}$ PRINCE2 to metodyka zarządzania projektami ukierunkowana na podejście produktowe. Propagowana jest przez APM Group Ltd, HM Government i TSO. Strona metodyki: www.prince-officialsite.com.

${ }^{7}$ Jedną z najbardziej znanych metodyk zwinnych jest Scrum. Metoda ta jest ukierunkowana na podejście produktowe. Wykorzystywana jest głównie w projektach IT. Strona metodyki: www.srum.org.pl.
} 
Zarządzanie projektami opiera się na metodzie zarządzania przez cele. Bardzo ważną kwestią jest tutaj poprawne zdefiniowanie systemu celów. Konieczne jest zdefiniowanie priorytetów strategicznych, które stanowią swoistą mapę drogową dla kierownictwa. Konfrontowanie bieżących decyzji z ustalonymi długofalowymi kierunkami rozwoju pozwala skoncentrować zasoby na najistotniejszych zadaniach. Jest to bardzo trudne w sytuacji, gdy tempo życia organizacyjnego, które zazwyczaj jest szybkie, nie pozwala na tego typu refleksję. Szczególnie duże trudności można zaobserwować w samorządzie, w którym ciągle w tle odbywa się niekiedy ostry spór polityczny lub przynajmniej konfrontacja różnych grup interesów. Tutaj właśnie należy upatrywać największych zagrożeń poprawnego stosowania omawianej metody w JST. Pozostałe z wymienionych obszarów można bowiem kształtować, odpowiednio przygotowując proces jej wdrożenia oraz procedury doskonalenia.

Mimo potencjalnie dużych oporów społecznych możliwe jest wprowadzenie w JST nowoczesnych rozwiązań organizacyjnych opartych na strukturze macierzowej oraz specjalizacji merytorycznej jednostek i komórek organizacyjnych. W wielu samorządach stosuje się już wyodrębnione zespoły projektowe tworzone do realizacji konkretnych projektów. Konieczne jest jednak rozszerzenie tego rozwiązania na inne przedsięwzięcia, które mają charakter projektów, choć są realizowane w ramach komórek liniowych. W uzyskaniu takiego stanu pomaga rozszerzenie pojęcia projektu również na te zadania, które nie są realizowane z wykorzystaniem środków zewnętrznych (głównie z Unii Europejskiej).

Wprowadzenie metody zarządzania projektami jest okazją do uporządkowania zadań realizowanych w całej JST oraz w poszczególnych jednostkach organizacyjnych. Główna oś podziału, wynikająca z metody, pozwala wyodrębnić dwie grupy zadań:

- tymczasowe (o czytelnym początku i końcu) - projekty;

- ciągłe - procesy.

Zastosowanie tego podziału pozwala przenieść realizację zadań tymczasowych ze struktury liniowej do projektowej. Oczywiście warto w tym wypadku kierować się przede wszystkim rozsądkiem i kryterium sprawności zarządzania. Oznacza to, że w praktyce część przedsięwzięć tymczasowych, zwłaszcza niewielkich i niewykraczających poza jedną komórkę, wciąż będzie realizowana w ramach struktury liniowej. Wyłonienie projektów i przekazanie do realizacji dedykowanym zespołom projektowym pozwala czytelnie wskazać osobę odpowiedzialną za realizację przedsięwzięcia (kierownika projektu), skoncentrować zasoby na realizacji zadań w projekcie oraz mierzyć uzyskane efekty. Wyodrębnione przedsięwzięcie łatwo też monitorować w trakcie realizacji.

Warto zwrócić jednak uwagę także na obszar procesów. W jednostkach organizacyjnych można zauważyć, że są one co prawda realizowane w sposób ciągły, jednak mają także wyodrębnione istotne daty związane z rozpoczęciem i zakończeniem roku budżetowego. Takie spojrzenie na procesy pozwala na przeniesienie filozofii zarządzania projektami na wszystkie zadania realizowane w JST. W ten sposób z orientacji projektowej skupiającej się na przedsięwzięciach tymczasowych można przejść na orientację zadaniową, która prezentuje podejście holistyczne. Dzięki temu łatwo wpisuje się zarówno w kontrolę zarządczą, jak i w budżetowanie zadaniowe.

Pozytywną konsekwencją wprowadzenia orientacji zadaniowej jest zastosowanie czytelnego podziału obowiązków ze wskazaniem właścicieli nie tylko projektów, ale także procesów. W samorządzie bowiem część zadań jest jednoznacznie przypisanych do konkretnych jednostek/komórek organizacyjnych (np. określona usługa administracyjna). 
Natomiast inne zadania, szczególnie związane z tworzeniem aktów prawnych, logistyką, zarządzaniem personelem czy zarządzaniem finansami, realizowana jest przez wiele komórek. Tutaj należy wyznaczyć osoby koordynujące przebieg całego procesu oraz jednoznacznie określić rolę pozostałych komórek/jednostek organizacyjnych.

Jednoznaczne wskazanie właścicieli zadań (osób odpowiedzialnych) ma daleko idące konsekwencje w obszarze personalnym. Po pierwsze, możliwa jest bezpieczna decentralizacja zarządzania i przekazanie wielu kompetencji (w tym uprawnień decyzyjnych) na poziom niższy. Uwalnia to władze jednostki samorządowej częściowo od spraw bieżących, pozostawiając czas na zarządzanie strategiczne. Dodatkowo pojawia się możliwość wprowadzenia niezwykle potrzebnego we wszystkich instytucjach SFP elastycznego wynagradzania od efektów. Ich identyfikacja oraz przypisanie do konkretnych osób lub komórek są bowiem zdecydowanie łatwiejsze.

Ostatnim ważnym obszarem związanym z wdrażaniem metody zarządzania projektami jest upowszechnienie technik zarządzania oraz narzędzi wspomagających ich wykorzystanie. Kompetencje w tym zakresie można budować na bazie szkoleń z powszechnie stosowanych metodyk lub wytycznych, takich jak IPMA, PMI czy PRINCE2. Ważne jest ich przełożenie na sposób postępowania w organizacji. Warto podkreślić, że zastosowanie zaawansowanych technik planowania jest w praktyce możliwe wyłącznie przy wsparciu narzędzi informatycznych zdolnych do przetworzenia dużej ilości danych w trybie ad hoc. Oprócz technik planowania i controllingu pracy czy wydatków, warto zwrócić uwagę na to, że w instrumentarium zarządzania projektami znajdują się techniki definiujące odnoszące się do zarządzania systemem celów, ryzykiem oraz relacjami z interesariuszami. Są one niezwykle istotne z punktu widzenia kontroli zarządczej.

Wymienione obszary stanowią bardzo szeroki zakres oddziaływania na organizację wdrażającą metodę zarządzania projektami. Szczegółowe ich omówienie przy ograniczonych rozmiarach niniejszej publikacji jest niemożliwe. Dlatego też w dalszej części skupiono się na zagadnieniach związanych $\mathrm{z}$ organizacją zarządzania projektami w JST oraz przebiegiem zadań. Stanowią one główną składową systemowego podejścia, które można określać mianem orientacji projektowej lub w bardziej kompleksowym wariancie - orientacji zadaniowej. Zdaniem autora bardziej odpowiedni dla JST jest właśnie wariant szerszy, obejmujący zastosowanie metody zarządzania projektami również w procesach. W związku z tym w dalszej części artykułu przyjęto właśnie taką perspektywę.

\section{WYMIAR ORGANIZACYJNY ORIENTACJI ZADANIOWEJ W JEDNOSTKACH SAMORZĄDU TERYTORIALNEGO}

Płaszczyzna organizacyjna orientacji zadaniowej jest fundamentalna ze względu na to, że tworzy warunki do zmiany w innych obszarach. Metoda zarządzania projektami wyznacza pewne standardy dotyczące zarówno struktury organizacyjnej, jak i ról organizacyjnych. Stanowią one na tyle istotną nowość, a przez to wyzwanie dla jednostek samorządu terytorialnego, że ich wprowadzenie można traktować jako przykład innowacji organizacyjnej. Wydaje się, że obecnie ze względu na wciąż małe upowszechnienie metody w instytucjach SFP można mówić o innowacji na skalę całego sektora, a nie tylko pojedynczego podmiotu.

Konstrukcja wymiaru organizacyjnego rozpoczyna się od utworzenia dwuwymiarowego układu struktury organizacyjnej, obejmującego komórki liniowe (stałe) oraz tymczasowe (rys. 1). W literaturze takie rozwiązanie określa się mianem struktury macierzo- 
wej. Jej charakterystyczną cechą jest jednoczesne funkcjonowanie przynajmniej części pracowników w obu wymienionych wymiarach. Przy rozwiniętej kulturze projektowej akceptowalna jest więc sytuacja, w której kierownik komórki liniowej, uczestnicząc w realizacji projektu, podlega $\mathrm{w}$ tym zakresie swojemu podwładnemu z komórki liniowej. W jednostkach administracji publicznej wprowadzenie takiej wymienności ról jest bardzo trudne kulturowo. Może więc istnieć tendencja do tego, aby przenosić układ zależności hierarchicznych z wymiaru liniowego do tymczasowego.

Warto podkreślić, że wprowadzanie struktury macierzowej ${ }^{8}$ odbywa się na poziomie jednostek organizacyjnych. Trzeba zatem przyjąć, że JST zorientowana zadaniowo to taka, w której nie tylko urząd, ale także inne jednostki organizacyjne przyjmują nowy sposób organizacji pracy.

Rys. 1. Przykład struktury macierzowej w jednostce organizacyjnej jednostki samorządu terytorialnego na przykładzie starostwa powiatowego

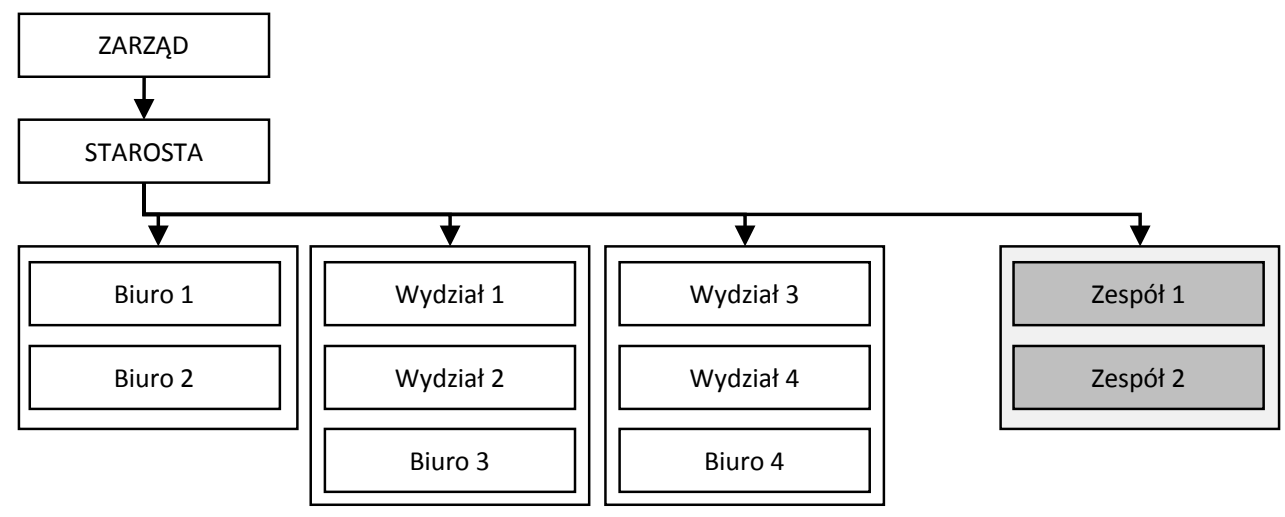

Źródło: opracowanie własne.

Wprowadzenie układu macierzowego w strukturze organizacyjnej nie wyczerpuje oczywiście zakresu dostosowań danego podmiotu do metody zarządzania projektami. W wymiarze organizacyjnym należy także analizować stworzenie nowych komórek organizacyjnych i ról związanych z realizacją zadań tymczasowych oraz opieką nad stabilnością całego systemu ${ }^{9}$ (System Zarządzania Projektami lub szerzej - System Zarządzania Zadaniami).

Do komórek organizacyjnych, które można wprowadzić, dostosowując samorządową jednostkę organizacyjną do orientacji zadaniowej, należą ${ }^{10}$ :

- $\quad$ komórka Project Management Office (PMO);

- zespół projektu;

- zespół programu;

- komitet sterujący projektu/programu.

\footnotetext{
${ }^{8}$ Szerzej: D. Lock, Podstawy zarzadzania projektami, PWE, Warszawa 2003, s. 47 i n.

${ }^{9}$ System Zarządzania Projektami/Zadaniami obejmuje zbiór rozwiązań zastosowanych w organizacji w celu sprawnej i efektywnej realizacji celów. W skład systemu wchodzą: struktura organizacyjna, dokumentacja systemowa, dokumentacja zawiązana z realizacją zadań, opisy procedur, narzędzia informatyczne itd.

${ }^{10}$ J. Strojny, Zarządzanie projektami innowacyjnymi, Politechnika Rzeszowska, Rzeszów 20012, s. 25 i n.
} 
Bardzo istotnym elementem dostosowania struktury organizacyjnej do zarządzania wyodrębnionymi przedsięwzięciami jest wprowadzenie komórki o charakterze PMO. Jest ona przeznaczona do tego, aby wspierać przygotowywanie i realizację projektów, dbając także o doskonalenie kompetencji projektowych. W wielu JST funkcjonują wyodrębnione komórki służące wsparciu pozyskiwania środków z Unii Europejskiej. Zakres ich działania nie jest jednak wystarczający do tego, aby określić je mianem PMO. Skupiają się bowiem najczęściej wyłącznie na wsparciu w zakresie wyszukiwania źródeł finansowania, przygotowywania wniosków oraz rozliczania projektów. Na bazie tych komórek można jednak utworzyć PMO, dodając także obowiązki związane z:

- zapewnieniem Systemu Zarządzania Projektami/Zadaniami (audyt i doskonalenie);

- rozwojem kompetencji projektowych;

- koordynacją portfeli projektów.

Wymieniona komórka ma charakter liniowy (stały). Natomiast pozostałe trzy tworzone są tymczasowo na czas realizacji przedsięwzięcia. Pierwsza z wymienionych to zespół projektu, tworzony z osób pracujących w komórkach liniowych na czas realizacji projektu. Ze względów organizacyjnych, w tym związanych z przechowywaniem dokumentów, warto wskazać, gdzie znajduje się biuro takiej komórki. Kluczem lokalizacji powinna być specyfika merytoryczna projektu. Na przykład zespoły projektów inwestycyjnych powinny być zlokalizowane w pomieszczeniach komórki liniowej zajmującej się inwestycjami. Oczywiście wyodrębnienie komórki ma także skutki w postaci zmiany schematu organizacyjnego oraz konieczności wprowadzenia na przykład oznaczenia pism.

Zespół programu jest również tworem tymczasowym, natomiast ma nieco mniej jednorodną strukturę. Tego typu komórki powołuje się do realizacji złożonych, długookresowych przedsięwzięć, obejmujących kilka lub więcej powiązanych ze sobą projektów, których realizacja rozciągnięta jest w czasie. W skład zespołu programu wchodzą głównie osoby kierujące projektami przyporządkowanymi do tych programów oraz oczywiście kierownik programu. Zakres działań obejmuje głównie koordynację projektów w celu uzyskania jak największej synergii oraz spójności programu w czasie.

W organizacjach zorientowanych projektowo można wyodrębniać także komitety sterujące projektu lub programu. Tego typu komórki mają charakter ciała kolegialnego, które wspiera przebieg przedsięwzięć, podejmując w imieniu zarządu lub kierownika jednostki decyzje strategiczne. W praktyce JST najprawdopodobniej będzie preferowane zatrzymanie tych kompetencji w dotychczasowym porządku, a więc na poziomie zarządu lub kierownika jednostki.

W wymienionych komórkach organizacyjnych można wyodrębnić następujące role:

- pełnomocnik ds. Systemu Zarządzania Projektami/Zadaniami;

- kierownik portfela projektów;

- kierownik projektu;

- kierownik programu;

- członek zespołu projektu/programu;

- przewodniczący komitetu sterującego.

Pierwsze dwie z wymienionych ról mają charakter liniowy i można je traktować jako stałe stanowiska pracy. Najbardziej optymalną ich lokalizacją jest komórka PMO. Pełnomocnik ds. Systemu Zarządzania Projektami/Zadaniami realizuje zadania związane $\mathrm{z}$ audytem oraz doskonaleniem rozwiązań systemowych przyjętych w organizacji. Najlepsze rezultaty w tym zakresie osiąga się, przeprowadzając cyklicznie (między innymi raz 
w roku) przeglądy systemu w celu weryfikacji zgodności istniejących rozwiązań z potrzebami jednostki oraz stopnia wykorzystania poszczególnych elementów systemu. Pełnomocnik powinien uaktualniać dokumentację, wprowadzając zmiany we wzorach dokumentów systemowych lub związanych z realizacją zadań. Odpowiedzialny jest także za monitorowanie i rozwijanie kompetencji projektowych, a szczególnie kształtowanie ścieżek kariery zawodowej dla kierowników projektów/programów.

Bardzo ważną rolę w organizacji odgrywa kierownik portfela. Odpowiada on za controlling operacyjny projektów/programów, zbierając informacje na temat stopnia realizacji zadań oraz uzyskiwanych efektów cząstkowych i końcowych. W zależności od szczegółowych rozwiązań w danej organizacji osoba na tego typu stanowisku może mieć też wiele kompetencji decyzyjnych, takich jak wskazanie osoby na stanowisko kierownika projektu, rozstrzyganie konfliktów między kierownikami projektów/programów, nakazanie przygotowania raportów itd. Silnie zaakcentowana rola kierownika portfela zwiększa skuteczność koordynacji wielu projektów realizowanych jednocześnie zarówno pod względem zasobowym, jak i wydatkowym. Jest także wyrazem decentralizacji, która pozwala na przeniesienie obciążeń związanych z reakcją na bieżące problemy w realizacji przedsięwzięć na poziom niższy niż zarząd czy kierownik jednostki.

Główną rolę w systemie opartym na metodzie zarządzania projektami odgrywa kierownik projektu. Wskazanie takiej osoby pozwala na jednoznaczne określenie odpowiedzialności za przebieg przedsięwzięcia, a przez to prowadzi do większej koncentracji na nim. Pozostawienie przedsięwzięć w ramach struktury liniowej nie tylko rozprasza odpowiedzialność, ale także utrudnia skoncentrowanie się na tych przedsięwzięciach ze względu na obciążenia zadaniami bieżącymi. Zdaniem autora w wypadku JST należy przyjąć zasadę, że kierownik projektu ma taki zakres odpowiedzialności i uprawnień względem przedsięwzięcia oraz podległego zespołu jak kierownik liniowy względem komórki liniowej i przypisanych do niej zadań ciągłych.

Kierownik portfela to osoba odpowiedzialna za realizację wielu rozciągniętych w czasie projektów. Należy jednak podkreślić, że nie zajmuje się on operacyjnie projektami (robią to kierownicy projektów), natomiast przede wszystkim koordynuje ich przebieg oraz dba o synergię pomiędzy nimi oraz komplementarność uzyskiwanych efektów. Uzasadnione wydaje się, że również kierownik portfela powinien mieć wpływ na wybór kierownika projektu przypisanego do danego programu.

Przewodniczący komitetu sterującego to rola, którą w pewnym sensie można utożsamiać z przełożonym kierownika projektu/programu. Może on więc podejmować wiążące decyzje dotyczące przedsięwzięcia, przy czym słuszne wydaje się przyjęcie, że ingerencja powinna dotyczyć raczej spraw strategicznych, a nie operacyjnych. W JST najbardziej prawdopodobna jest sytuacja, w której rolę tę przyjmie kierownik jednostki bądź wskazany przez niego, właściwy merytorycznie zastępca.

\section{PRZEBIEG ZADAŃ W JEDNOSTCE SAMORZĄDU TERYTORIALNEGO ZORIENTOWANEJ ZADANIOWO}

Podział pracy wymaga nie tylko określenia założeń organizacyjnych, ale także zbudowania odpowiedniej struktury pracy. W JST zorientowanej zadaniowo właściwe jest przyjęcie pewnej hierarchii zadań, obejmującej zadania strategiczne i operacyjne, oraz klasyfikacji pozwalającej rozdzielić zadania ciągłe od tymczasowych. Mając to na uwadze, można wymienić następujące typy zadań: 
- proces strategiczny główny;

- proces strategiczny funkcjonalny;

- program;

- projekt $^{11}$;

- proces operacyjny.

Głównym zadaniem strategicznym jest proces rozwoju społeczno-gospodarczego jednostki samorządu terytorialnego. Ma on charakter ciągły i jest realizowany w układzie wieloletnim. Podstawowym dokumentem programującym wykonanie tego zadania jest strategia rozwoju gminy, powiatu czy regionu. Oczywiście rozwój nie jest zjawiskiem jednorodnym i wymaga sprecyzowania obszarów funkcjonalnych (innowacyjność, infrastruktura, szkolnictwo, kultura, ochrona środowiska itd.). Dlatego też uzasadnione jest rozpisanie tak zwanych procesów strategicznych funkcjonalnych, które stanowią podstawę do wyznaczenia priorytetów strategicznych (najważniejsze obszary rozwoju).

Określenie priorytetów pozwala jednostkom samorządowym skupić się na ich realizacji. Znajduje to wyraz w koncentracji zasobów, zarówno finansowych (budżety w kolejnych latach realizacji strategii), jak i ludzkich (zaangażowanie pracowników). Opierając się na metodzie zarządzania projektami, warto wprowadzić zadania o charakterze programów. Służą one do osiągnięcia określonych celów średnio- i długofalowych głównie w obszarach uznanych za priorytetowe.

Rys. 2. Schemat zadań w jednostki samorządu terytorialnego zorientowanej zadaniowo

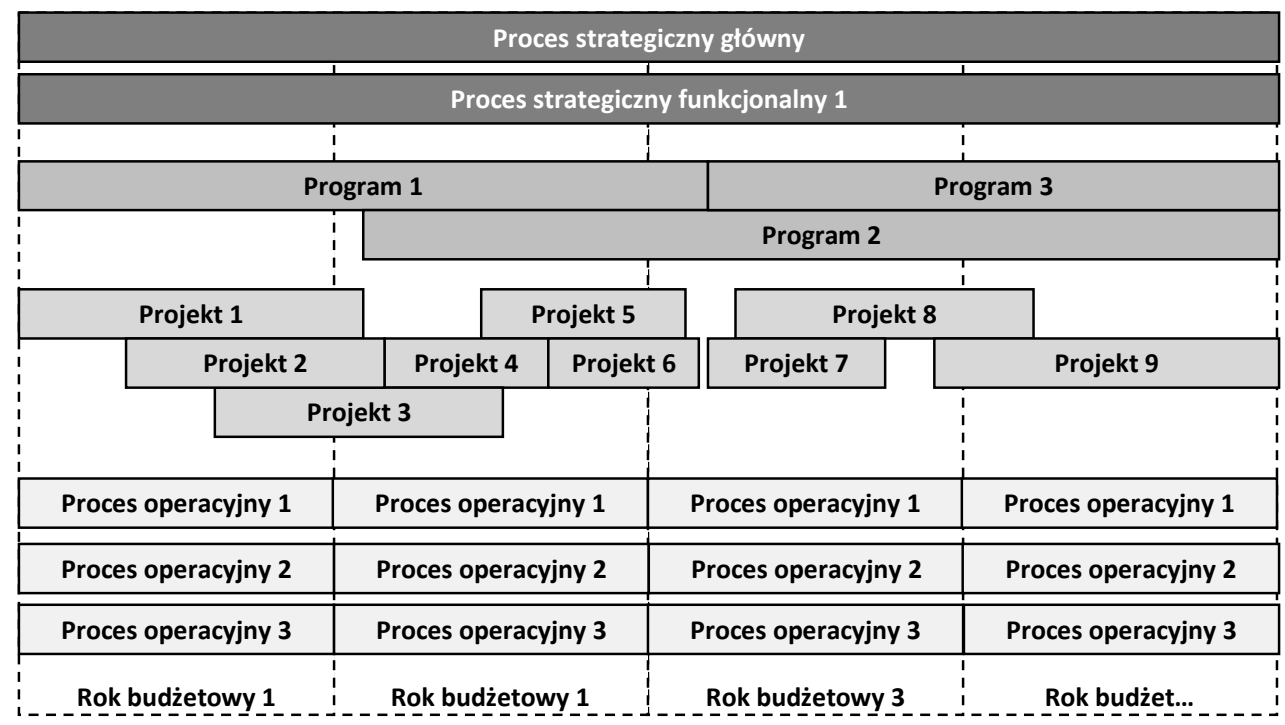

Źródło: opracowanie własne.

\footnotetext{
${ }^{11}$ Polskie wytyczne kompetencji IMPA określają projekt jako unikatowy zestaw skoordynowanych działań, ograniczony czasem i kosztami, mający na celu uzyskanie określonych uprzednio produktów (zakres spełniający cele projektu), zachowujący przy tym normy jakości i wymagania (Polskie Wytyczne Kompetencji IPMA, red. B. Dałkowski i in., SPMP, Gdańsk 2009, s. 15). Por. także: PRINCE2 ${ }^{T M}$ - Skuteczne zarzadzanie projektami, TSO, GB 2010, s. 3, oraz PMBok Guide 4th Edition, Project Management Institute, USA 2008, s. 5.
} 
Na poziomie operacyjnym występują dwa kolejne rodzaje zadań: projekty (tymczasowe) oraz procesy operacyjne (ciągłe). Przedsięwzięcia o charakterze projektów mogą być realizowane zarówno w ramach przyjętych programów, jak i poza nimi. Moment ich rozpoczęcia zależy od indywidualnego harmonogramu i nie musi pokrywać się z początkiem roku budżetowego. Co prawda procesy operacyjne są ciągle realizowane, można je jednak podzielić na zadania trwające rok budżetowy - rozpoczęcie i zakończenie zbieżne odpowiednio z początkiem i końcem roku budżetowego.

Każdy z wymienionych rodzajów zadań może zostać wpisany w uniwersalny schemat przebiegu (model fazowy), obejmujący fazę inicjacji, przygotowania, realizacji oraz zamknięcia. Pierwsze dwie wiążą się z przygotowaniem planu działania. W fazie inicjacji określa się nie tylko podmiot i osoby odpowiedzialne, ale także analizuje cele, interesariuszy czy ryzyko związane realizacją danego zadania. W fazie planowania przygotowuje się plan bazowy zadania, obejmujący: plan pracy, harmonogram zadań oraz plan finansowy. $\mathrm{W}$ fazie realizacji wykonuje się zadania merytoryczne a ponadto prowadzi controlling operacyjny, pozwalający na bieżąco zbierać i oceniać postępy w realizacji zadania. Ostatnia $\mathrm{z}$ wymienionych faz służy podsumowaniu przebiegu zadania oraz jego rozliczeniu.

Rys. 3. Uniwersalny model fazowy zadania

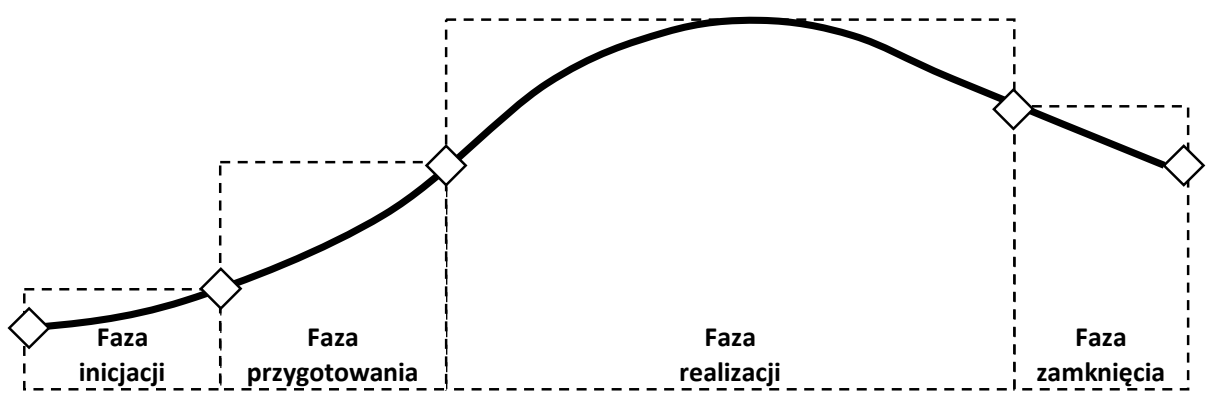

Źródło: opracowanie własne na podstawie: J.D. Frame, Zarządzanie projektami w organizacjach, WIG-PRESS, Warszawa 2001, s. 7 i n.

Oczywiście szczegółowe procedury przejścia przez model fazowy różnią się w zależności od rodzaju zadania. W wypadku zadań strategicznych (głównych i funkcjonalnych) inicjacja i przygotowanie wiąże się z tworzeniem dokumentu strategicznego. Faza realizacji rozłożona jest na wiele lat i wymaga cyklicznego, najlepiej corocznego monitoringu. W wypadku projektów i programów przebieg faz jest podobny. Inicjacja rozpoczyna się wraz z decyzją o uruchomieniu danego zadania. Następnie przygotowywany jest plan bazowy. Zgodnie z nim postępuje faza realizacji, a następnie zamknięcie przedsięwzięcia. Ostatni typ zadania, czyli procesy operacyjne, inicjowane i planowane są w roku poprzedzającym rok budżetowy (przygotowanie uchwały budżetowej). Natomiast faza zamknięcia występuje już w roku następnym po roku budżetowym. Faza realizacji zaś pokrywa się dokładnie $\mathrm{z}$ danym rokiem budżetowym.

\section{PODSTAWOWE WNIOSKI}

Przedstawione w niniejszym artykule aspekty są zdaniem autora istotne z punktu widzenia wyzwań rozwojowych stojących przed jednostkami samorządu terytorialnego. 
Rosnąca presja skierowana na wzrost efektywności i skuteczności działania wymusza poszukiwanie takich rozwiązań, które pozwalają osiągnąc te parametry. Najlepszym ich źródłem jest sektor przedsiębiorstw działających na konkurencyjnym rynku. Metody i techniki dostosowane do działalności biznesowej pozwalają optymalizować ograniczone zasoby pod kątem przyjętych kierunków rozwojowych, dzięki czemu przedsiębiorstwa mogą sprawniej działać. W nowych warunkach funkcjonowania samorządów pojawia się postulat ich „ubiznesowienia”. Chodzi tutaj oczywiście nie tyle o stworzenie z nich organizacji nastawionych na zysk, ile o zwiększenie racjonalności podejmowanych decyzji oraz uzyskanie wysokiej sprawności działania.

Nowy reżim prawny, w tym regulacje dotyczące kontroli zarządczej, oraz proces związany z wprowadzaniem budżetowania zadaniowego stwarzają sprzyjające warunki do zmian. Jednostki samorządu terytorialnego są bowiem wtłaczane w nowe ramy realizacji procesu zarządzania. Tutaj z pomocą przychodzi metoda zarządzania projektami, która znajduje się już w zaawansowanej fazie cyklu życia. Dzięki temu można znaleźć wiele narzędzi służących do wsparcia procesu zarządzania - zarówno technik zarządzania, jak i programów komputerowych.

Podejście holistyczne proponowane i częściowo omówione w artykule ma charakter reengineeringu. Jest to więc zmiana totalna (radykalna) i jako taka stwarza duże problemy realizacyjne, a więc także ryzyko niepowodzenia, przy jednocześnie potencjalnie znacznych efektach związanych ze wzrostem sprawności działania. Zdaniem autora wprowadzenie tego typu rozwiązań należy rozpocząć od urzędu, przetestować w warunkach danej JST oraz ocenić i ewentualnie zmodyfikować, dostosowując do jej specyfiki. Dopiero wówczas można rozpoczynać proce upowszechniania wypracowanych standardów na inne jednostki organizacyjne. Proces takich dostosowań może nawet wykraczać poza ramy jednej kadencji, a jego realizację warto zaplanować w postaci programu.

\section{LITERATURA}

[1] Frame J.D., Zarządzanie projektami w organizacjach, WIG-PRESS, Warszawa 2001.

[2] Lewis J.P, Podstawy zarzadzania projektami, Helion, Gliwice 2005.

[3] Lock D., Zarządzanie projektami, PWE, Warszawa 2009.

[4] PMBok Guide 4th Edition, Project Management Institute, USA 2008.

[5] Podręcznik Oslo, OECD/European Communites, Warszawa 2008.

[6] Polskie Wytyczne Kompetencji IPMA, red. B. Dałkowski, L. Staśko, M. Zalewski, Stowarzyszenie Project Management Polska, Gdańsk 2009.

[7] Porter M.E., Competitive Advantage, Free Press, New York 1985.

[8] PRINCE2 ${ }^{\mathrm{TM}}$ - Skuteczne zarządzania projektami, TSO, GB 2010.

[9] Skorupka D., Kuchta D., Górski M., Zarządzanie ryzykiem w projekcie, Wyższa Szkoła Oficerska Wojsk Lądowych we Wrocławiu, Wrocław 2012, s. 9.

[10] Strojny J., Zarządzanie projektami innowacyjnymi, Politechnika Rzeszowska, Rzeszów 2012.

\section{ORGANIZATIONAL AND PROCEDURAL DETERMINATIONS OF PROJECT MANAGEMENT IN A UNIT OF LOCAL GOVERNMENT}

The article describes some aspects of the implementation of project management methods in local government units. The essence of this method was discussed, paying attention to the possibility of its use in such institutions. It also refers to the dimension of organizational design orientation. There were analyzed both, the narrow scope of the reorganization, which 
is to improve performance of the projects, as well as a variant of radical change, which refers to many areas of activity. The paper discusses the organization of work focused on service projects and necessary changes in procedures relating to such projects.

Solution diagram presented in the article is embedded in the literature, in particular, it is based on publications that describe the most important project management methodologies IPMA, PMI and PRINCE2. The assumptions presented which regard the use of this method should be translated into specific organization of local government, creating a foundation implementation. The dimensions mentioned in the article - organizational and procedural orientation of the basic elements of design define the scope of the project orientation. These are also areas of difficult changes in public institutions, mainly due to legal constraints, and sometimes also mental barriers. At the same time there were discussed the conditions for the functioning local government in present environment force search of organizational innovations that improve efficiency and rationality of spending public funds. Scheme described in this paper is a part of the change needed from point of view mobile capital market requirements, regulatory changes resulting from the implementation of management control, and trends in the implementation of task budgeting.

Keywords: project management, project orientation, local government, regional government

DOI: $10.7862 /$ rz.2014.mmr.26

Tekst złożono w redakcji: kwiecień 2014

Przyjęto do druku: czerwiec 2014 